\title{
Pendayagunaan Teknologi di Klaster Komponen Kapal Desa Kebasen, Kecamatan Talang, Kabupaten Tegal
}

\author{
Alifya Arinal Haq ${ }^{1}$ \\ Diterima : 18 September 2013 \\ Disetujui : 4 Oktober 2013
}

\begin{abstract}
The Central Java government uses a cluster growth approach to develop small industrial sector. Cluster development constitutes one of many concerns in local economic growth. Tegal has some clusters, one of them is ship components cluster in Kebasen Village, Talang Sub-District. Cluster has many problems related to technology which hampers its development. The goal of this research is to review the utilization of technology in ship components cluster in Kebasen Village, Talang Sub-District, Tegal District. This research is a quantitative research where the analysis method uses qualitative descriptive and quantitative descriptive (scoring and t-test). The result of research is the level of technology utilization in this cluster is counted low. This cluster is yet to require a high technology due to some factors, including production necessity which is in small and medium enterprise, economic condition and human resources of workers. The technology utilization in the cluster uses manual production and manual electric equipments.
\end{abstract}

Keywords: industrial cluster, technology utilization, success rate, the influence of the technology utilization

\begin{abstract}
ABSTRAK
Pemerintah Provinsi Jawa Tengah menggunakan pendekatan pengembangan klaster dalam mengembangkan sektor industri kecil. Pengembangan klaster merupakan salah satu fokus dalam pengembangan ekonomi lokal. Kabupaten Tegal memiliki beberapa klaster usaha, salah satunya adalah klaster komponen kapal Desa Kebasen, Kecamatan Talang. Klaster memiliki beberapa permasalahan terkait teknologi yang menghambat pengembangannya. Tujuan dari penelitian ini adalah untuk mengkaji pendayagunaan teknologi di klaster komponen kapal Desa Kebasen, Kecamatan Talang, Kabupaten Tegal. Penelitian ini merupakan penelitian kuantitatif dimana metode analisisnya menggunakan deskriptif kualitatif dan deskriptif kuantitatif (skoring dan uji beda ratarata). Hasil dari penelitian ini yaitu secara keseluruhan tingkat pendayagunaan teknologi di klaster komponen kapal termasuk rendah. Klaster belum membutuhkan high technology karena disesuaikan dengan kebutuhan produksi yang masih kelas usaha kecil dan menengah, kondisi ekonomi, dan SDM pelaku usaha. Pendayagunaan teknologi di dalam klaster menggunakan peralatan produksi manual dan manual elektrik.
\end{abstract}

Kata kunci: klaster industri, pendayagunaan teknologi, tingkat keberhasilan, pengaruh pendayagunaan teknologi

\footnotetext{
${ }^{1}$ Mahasiswa Magister Pembangunan Wilayah dan Kota, Undip, Semarang, Jawa Tengah Kontak Penulis : alifya.planologi@gmail.com
} 


\section{PENDAHULUAN}

Di Jawa Tengah, pengembangan usaha kecil dan menengah diterapkan dengan konsep klaster. Pengembangan klaster merupakan salah satu fokus dalam pengembangan ekonomi lokal yang bertujuan untuk mengangkat potensi wilayah sehingga dapat memberikan keuntungan ekonomi terutama bagi masyarakat. Kabupaten Tegal merupakan salah satu kabupaten di Jawa Tengah yang memiliki beberapa klaster yang dikembangkan oleh pemerintah, salah satunya Klaster komponen kapal yang terletak di Desa Kebasen, Kecamatan Talang. Klaster komponen kapal merupakan klaster yang sangat potensial dan merupakan kompetensi inti industri di Kabupaten Tegal karena industri ini dianggap memiliki kompetensi lebih daripada IKM pengecoran logam lain. Peran teknologi sangat penting dalam klaster berbasis industry. Selain merupakan salah satu pilar penting dalam pengembangan wilayah seperti yang diungkapkan M.T.Zen (1980) dalam Alkadri (1999), pendayagunaan teknologi juga merupakan bagian dari penerapan knowledge economy dimana produktivitas dan pertumbuhan ekonomi di suatu wilayah bukan semata-mata dipengaruhi oleh kelimpahan sumberdaya alam namun lebih kepada meningkatkan kualitas SDM dan faktor produksi, dan untuk menciptakan pengetahuan an menggabungkannya ke dalam peralatan dan orang (David dan Foray, 2003 dalam Cooke, et.al, 2007).

Klaster komponen kapal Desa Kebasen, Kecamatan Talang, Kabupaten Tegal juga mendayagunakan teknologi di dalam menjalankan produksinya. Namun terdapat beberapa permasalahan terkait teknologi yang menghambat pengembangan unit usaha klaster. Permasalahan ini seperti keterbatasan peralatan produksi, usia mesin yang sudah tua yaitu Tahun 1970/1980-an dikarenakan keterbatasan modal usaha, selain itu terdapat beberapa peralatan produksi yang harus di-upgrade dikarenakan masih sangat tradisional. Permasalahan terkait teknologi ini menyebabkan produktivitas usaha kurang sehingga hasilnya kurang maksimal dan masih sulit dalam mengejar omset, selain itu berdampak pula pada mutu/kualitas produk yang masih sulit untuk dipertahankan, padahal produk komponen kapal harus dapat memenuhi standar nasional kebutuhan alat transportasi laut. Penelitian ini bertujuan untuk mengkaji pendayagunaan teknologi di klaster komponen kapal Desa Kebasen, Kecamatan Talang, Kabupaten Tegal.

\section{METODE PENELITIAN}

Penelitian tentang pendayagunaan teknologi di klaster komponen kapal Desa Kebasen, Kecamatan Talang, Kabupaten Tegal ini menggunakan pendekatan penelitian kuantitatif. Penelitian ini memiliki kejelasan unsur, direncanakan dengan matang sejak awal, terdapat research question yang tertuang dalam perumusan masalah, berdasar pada teori yang telah ada sebelumnya, dan memiliki desain yang jelas namun dalam pengumpulan dan analisis data menggunakan metode campuran. Pengumpulan data menggunakanobservasi, kuesioner kepada seluruh unit usaha klaster komponen kapal yaitu sebanyak 29 unit usaha, dan wawancara dengan koperasi komponen kapal, pelaku usaha, serta Bappeda dan Disperindag Kabupaten Tegal. Analisis data dilakukan dengan analisis deskriptif kuantitatif yang di dalamnya meliputi statistik deskriptif, skoring, dan uji beda rata-rata (t-test) serta analisis deskriptif kualitatif. Untuk lebih jelasnya mengenai alur penelitian, dapat dilihat pada bagan di bawah ini: 


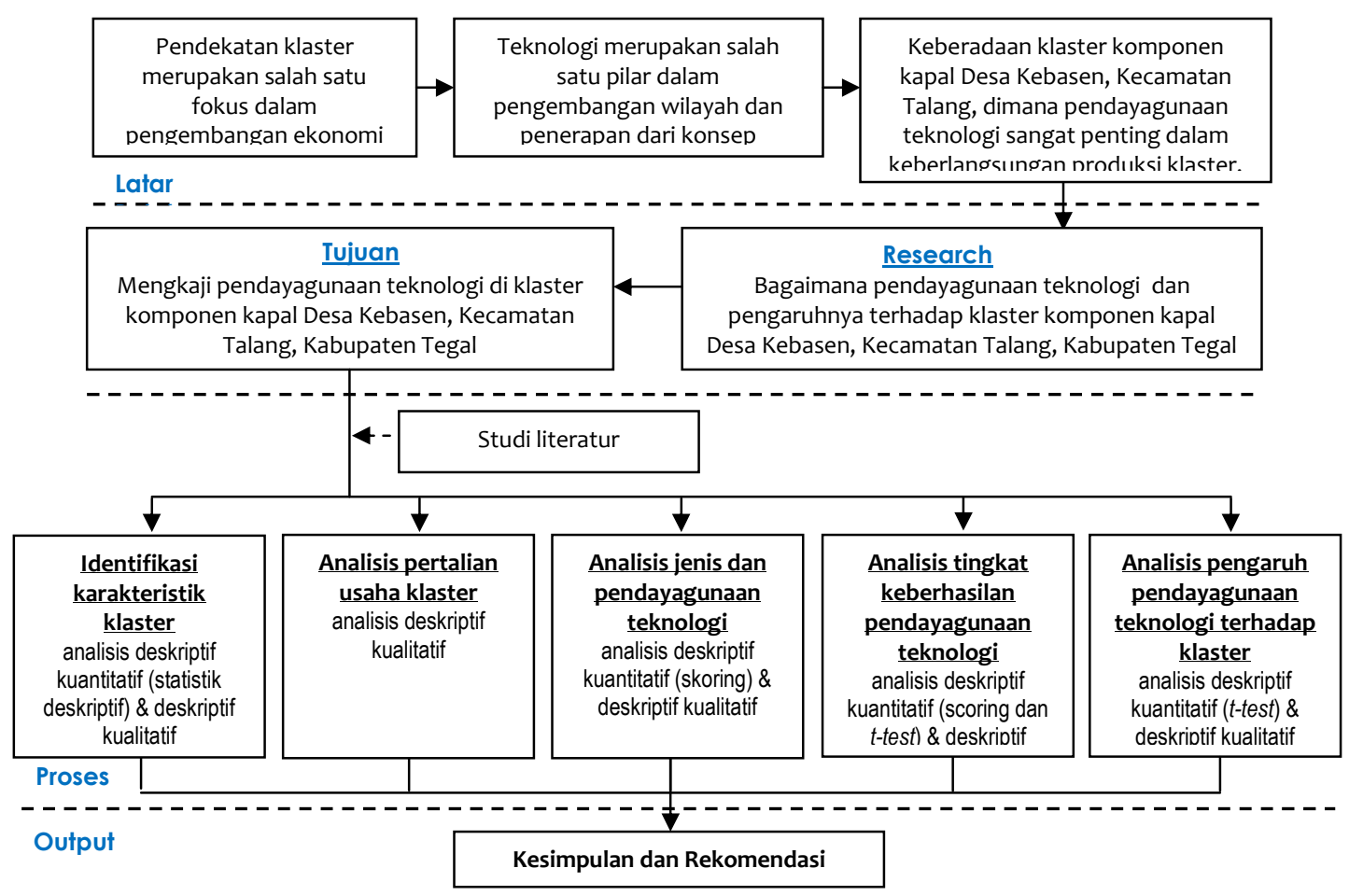

Sumber : Analisis Penyusun, 2013

GAMBAR 1

KERANGKA ANALISIS

\section{GAMBARAN UMUM}

Kecamatan Talang terletak di Kabupaten Tegal di bagian Utara dekat dengan Kota Tegal. Kecamatan Talang terbagi menjadi 19 desa, salah satunya Desa Kebasen. Desa Kebasen memiliki potensi yaitu dengan adanya Klaster Komponen Kapal. Industri komponen kapal juga telah ada sejak jaman kolonial Belanda dan merupakan bagian dari industri logam potensial di Kabupaten Tegal. Inisiasi pembentukan klaster komponen kapal dimulai tahun 2003 bersama beberapa klaster logam lainnya. Tahun 2008 klaster ditetapkan sebagai kompetensi inti industri daerah oleh Kementrian Perindustrian

Klaster komponen kapal terdiri dari 29 unit usaha yang tergabung di dalam Koperasi yaitu Koperasi Mandiri Sejahtera, namun saat ini koperasi belum berjalan baik.

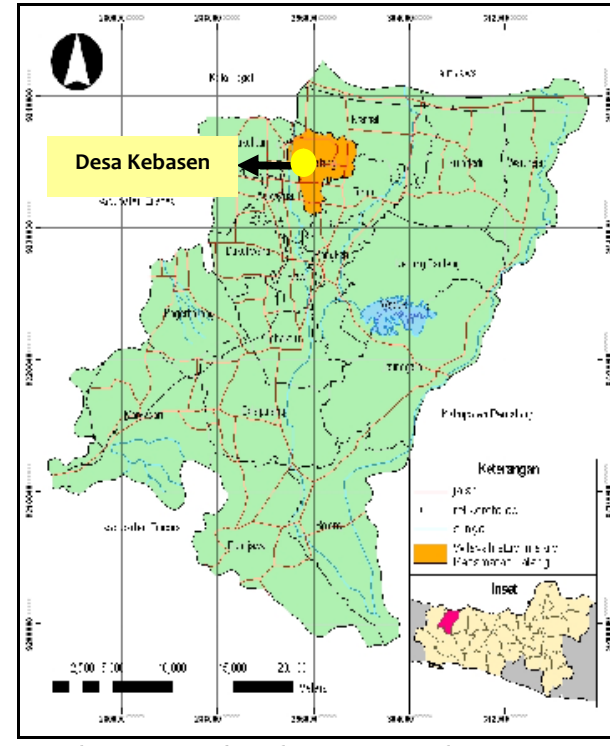

Sumber : Bappeda Kabupaten Tegal, 2011

GAMBAR 2

PETA WILAYAH STUDI PENELITIAN 


\section{KAJIAN TEORI}

Pengembangan wilayah Menurut M.T.Zen (1980) dalam Alkadri (1999), memiliki 3 (tiga) pilar penting, yaitu pilar sumberdaya alam, sumberdaya manusia, dan teknologi. Upaya pengembangan wilayah pada hakekatnya merupakan upaya pemberdayaan masyarakat untuk memanfaatkan sumberdaya alam dan lingkungan di sekitarnya dengan dukungan teknologi yang dimiliki atau dikuasainya. Selain sebagai bagian dari tiga pilar penting pengembangan wilayah, pendayagunaan teknologi juga merupakan penerapan dari konsep knowledge economy yang mengacu pada ekonomi dimana produktivitas dan pertumbuhannya bukan semata-mata berbasis pada ketersediaan atau kelimpahan sumberdaya alam tetapi lebih kepada kapasitas untuk meningkatkan kualitas sumberdaya manusia dan faktor produksi dan untuk menciptakan pengetahuan baru dan ide-ide dan menggabungkannya ke dalam peralatan dan orang (David dan Foray, 2003 dalam Cooke, et.al, 2007).

Pengembangan wilayah salah satunya dilakukan dengan pendekatan pengembangan klaster. Dalam rangka mewujudkan pengembangan klaster, terdapat banyak praktek pendayagunaan/adopsi teknologi. Menurut Rietveld (1987), adopsi atau pendayagunaan merupakan pemanfaatan produk baru dalam proses produksi dimana produk tersebut dapat berupa barang, mesin/peralatan, ide, maupun teknologi. Sedangkan definisi dari teknologi itu sendiri menurut Smillie (1991:65) dalam Albu (1997), merupakan ilmu dan seni dalam menyelesaikan sesuatu melalui penerapan ketrampilan dan pengetahuan dimana konsepnya merupakan campuran dari pengetahuan, teknik, dan alat. Teknologi menurut ESCAP (1988b:22-28,50) dalam Alkadri (1999), tersusun dari 4 (empat) komponen, diantaranya:

1. Technoware $(\mathrm{T})$, yaitu perangkat teknis yang digunakan dalam mengoperasikan suatu transformasi produksi.

2. Humanware $(H)$, yaitu kemampuan sumberdaya manusia yang meliputi pengetahuan, ketrampilan/keahlian, kebijakan, kreativitas, dan pengalaman dalam memanfaatkan sumberdaya alam dan teknologi yang tersedia.

3. Inforware (I), yaitu perangkat informasi yang berkaitan dengan proses, prosedur, teknik, metode, teori, dan lain sebagainya.

4. Orgaware (O), disebut juga dengan perangkat organisasi/kelembagaan dan peraturan yang dibutuhkan untuk mewadahi perangkat teknis, kemampuan sumberdaya manusia, dan perangkat informasi.

Untuk mengukur kinerja atau keberhasilan teknologi yang diadopsi di dalam industri kecil, terdapat beberapa faktor yang menjadi tolak ukur. Menurut Sudarmo (2005) dalam Mizar (2008), terdapat 4 (empat) faktor tingkat keberhasilan pendayagunaan teknologi, diantaranya:

1. Kelayakan teknis, dimana teknologi harus bisa menghasilkan nilai tambah, membantu proses produksi, hemat dalam menggunakan sumberdaya, serta awet.

2. Faktor ekonomis, dimana teknologi harus dapat meningkatkan keuntungan finansial.

3. Penerimaan oleh masyarakat, dimana teknologi harus dapat diterima dan diadopsi di masyarakat, bermanfaat, dapat dijangkau dalam hal harga, serta sesuai dengan budaya masyarakat.

4. Keserasian dengan lingkungan, dimana pendayagunaan teknologi harus serasi dengan lingkungan dan tidak menimbulkan pencemaran.

Keberadaan teknologi tentu membawa pengaruh atau dampak serta manfaat bagi klaster atau industri kecil dan menengah yang kemudian berdampak juga bagi pengembangan wilayah. Jika ditinjau dari pengaruhnya terhadap aspek produksi, teknologi dapat meningkatkan produktivitas, efisiensi waktu, dan volume produksi. Selain itu teknologi juga dapat 
menurunkan produk cacat dikarenakan proses produksi tidak lagi didominasi oleh manusia (Knaap dan Wever, 2003; Ellitan, 2003; Youseff, 1993).

\section{ANALISIS}

\section{Identifikasi kondisi Klaster}

Klaster komponen kapal merupakan salah satu klaster yang potensial di Provinsi Jawa Tengah. Keberadaan klaster ini ditetapkan oleh Kementrian Perindustrian menjadi kompetensi inti daerah di Kabupaten Tegal, karena dianggap memiliki prospek yang lebih baik ke depannya, mengingat kebutuhan akan industri kapal terus menerus diperlukan karena Indonesia merupakan Negara Maritim, serta Tegal yang berada di Wilayah Pantai Utara Pulau Jawa.

Klaster komponen kapal terletak di Desa Kebasen, Kecamatan Talang yang notabene merupakan sentra pengecoran logam. Namun tidak semua pengusaha logam di Desa Kebasen menghasilkan komponen kapal, beberapa memproduksi alat pemadam, alat rumah tangga, alat listrik, dan alat mesin pertanian. Pelaku usaha klaster komponen kapal berdasarkan data Disperindag dan koperasi sebanyak 29 unit usaha. Unit usaha ini diklasifikasikan menjadi 3 Kelompok berdasarkan proses dan pendayagunaan teknologinya yaitu Mixed technology (campuran antara pendayagunaan teknologi tradisional dan non tradisional) sebanyak 23 unit usaha, Non Traditional Technology sebanyak 5 unit usaha, dan Fully Traditional Technology sebanyak 1 unit usaha.

Secara keseluruhan, unit usaha di klaster komponen kapal berbentuk UD. Sebagian besar unit usaha merupakan usaha turun menurun keluarga, namun ada pula pelaku usaha yang merintis sendiri usahanya dari awal. Pengusaha logam menjalani proses pembelajaran produksi secara otodidak, namun ada pula yang merupakan SMK/STM (sekolah teknik), sehingga sudah memiliki bekal pengetahuan dan ketrampilan kaitannya dengan industri perlogaman dan permesinan. Modal yang dibutuhkan dalam usaha komponen kapal diantaranya modal bahan baku, modal peralatan produksi (mesin-mesin), dan modal tempat. Jumlah tenaga kerja di masing-masing unit usaha sebagian besar di bawah 10 orang.

\section{Analisis Pertalian Usaha}

Dalam menjalankan produksinya, para pelaku usaha dibantu oleh stakeholder-stakeholder lain mulai dari proses penyediaan input hingga pemasaran. Dalam analisis pertalian usaha ini, akan dibahas mengenai peran masing-masing stakeholder dalam setiap tahapan produksi klaster. 


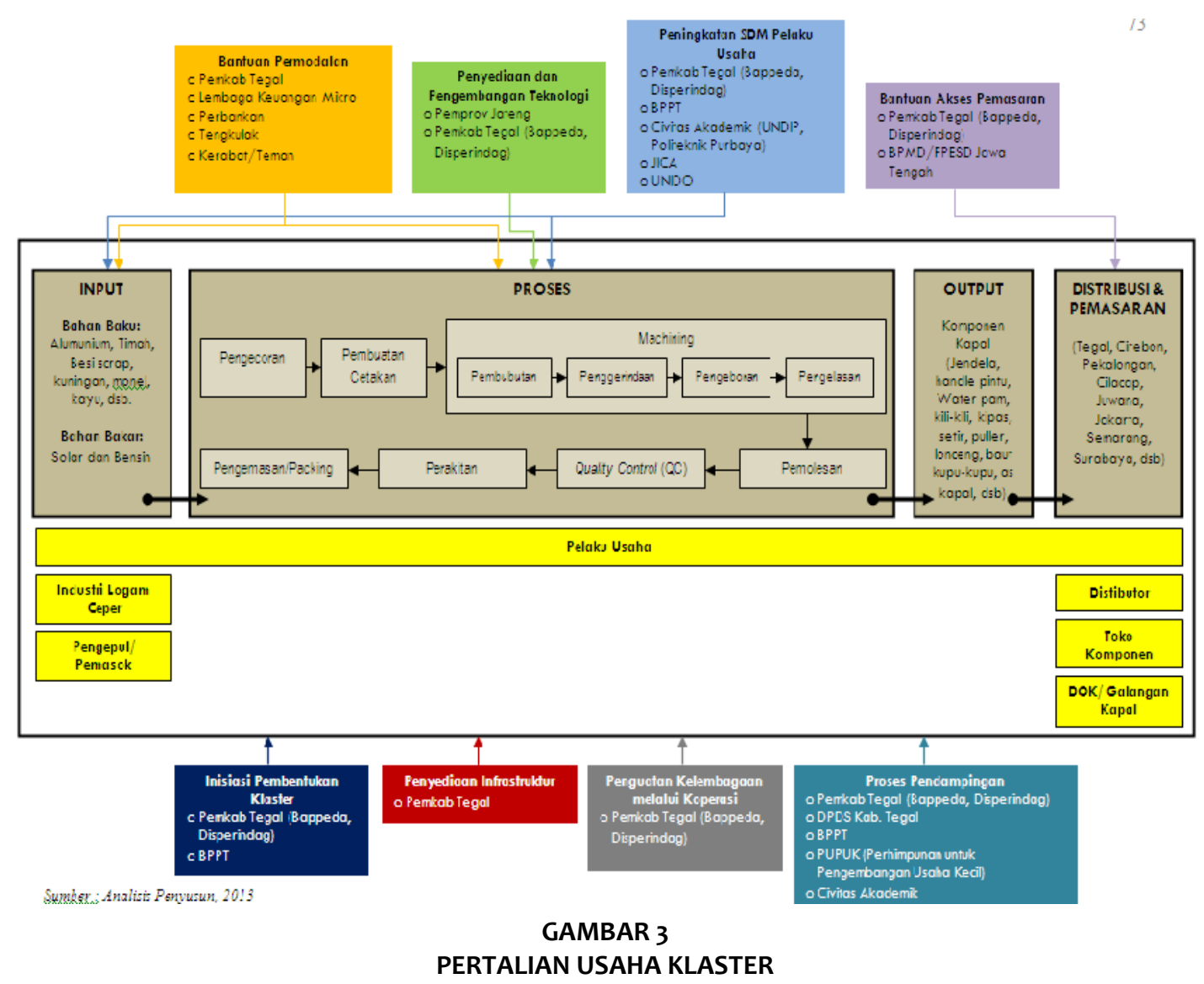

Analisis Jenis dan Pendayagunaan Teknologi

Alur pendayagunaan teknologi di klaster komponen kapal berbeda-beda, tergantung pada produk yang dihasilkan, namun secara umum peralatan produksi yang digunakan sama. Secara general, alur pendayagunaan teknologi terdiri dari proses pengecoran menggunakan kompor tradisional, proses pencetakan menggunakan cetakan tanah dan besi yang dilakukan secara manual, kemudian proses machining yang mulai melibatkan peralatan yang lebih modern yaitu menggunakan mesin-mesin yang sudah menggunakan listrik diantaranya mesin bubut, mesin bor, mesin gerinda, mesin las, mesin frais, mesin tapping, dan lain sebagainya. Selanjutnya yaitu proses finishing yaitu pemolesan, pengecatan, dan perakitan yang dilakukan secara manual. Alur produksi general termasuk dalam klasifikasi mixed technology, untuk

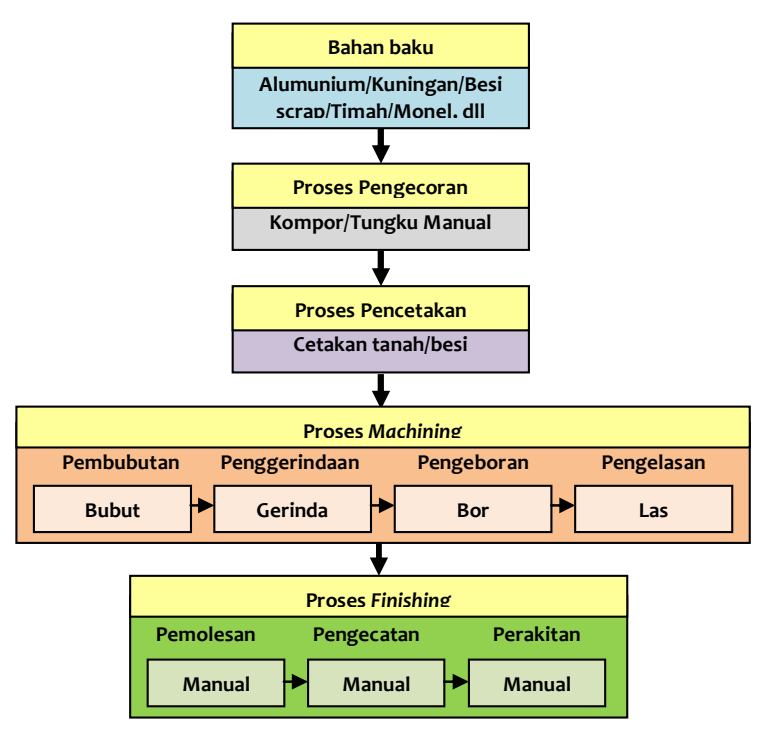

Sumber : Analisis Penyusun, 2013

GAMBAR 4

ALUR PENDAYAGUNAAN TEKNOLOGI GENERAL 
klasifikasi non traditional, proses pembuatan produknya tidak mengalami proses pengecoran sehingga dari bahan baku langsung ke proses machining. Untuk klasifikasi fully traditional secara keseluruhan menggunakan peralatan produksi manual mulai dari pengecoran sampai dengan finishing.

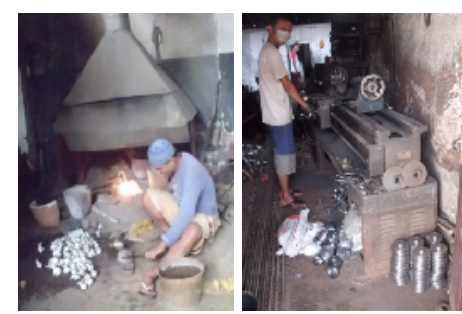

Sumber: Analisis Penyusun, 2013

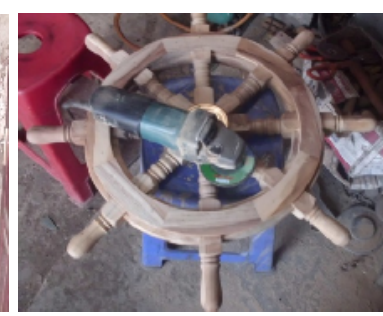

GAMBAR 5

\section{PENDAYAGUNAAN TEKNOLOGI DI KLASTER}

Keberadaan industri logam dan komponen kapal Desa Kebasen, Kecamatan Talang sudah ada sejak lama, dan jika ditinjau dari teknologinya terdapat beberapa peralatan produksi yang mengalami perubahan/perkembangan dari yang semula manual menjadi manual elektrik seperti pada mesin bubut, gerinda, bor, tapping, dan gergaji. Namun perubahan teknologi hanya dialami oleh beberapa pelaku usaha saja, sebagian besar pelaku usaha menyatakan dari awal merintis hingga saat ini teknologi machining yang digunakan telah menggunakan listrik, dan pengembangan usaha kaitannya dengan teknologi dilakukan dengan penambahan peralatan produksi saja. Perubahan/perkembangan teknologi juga diwujudkan dalam bentuk perbaikan metode produksi dengan adanya program Gugus Kendali Mutu (GKM), sehingga proses produksi lebih prosedural dan sudah ada pembagian tugas tenaga kerja.

Tingkat pendayagunaan teknologi di klaster komponen kapal dinilai dengan mempertimbangkan komponen technoware, humanware, inforware, dan orgaware termasuk dalam tingkat pendayagunaan teknologi rendah. Berikut adalah hasil penilaian tingkat pendayagunaan teknologi yang didapat dari skoring berdasarkan persepsi pelaku usaha.

TABEL 1

\section{MATRIKS SIZE USAHA DAN TINGKAT PENDAYAGUNAAN TEKNOLOGI DI KLASTER KOMPONEN KAPAL}

\begin{tabular}{|c|c|c|c|c|c|c|}
\hline & \multirow{2}{*}{$\begin{array}{l}\text { Jumlah } \\
\text { UU }\end{array}$} & \multicolumn{2}{|c|}{ Size (Rata-Rata) } & \multicolumn{3}{|c|}{$\begin{array}{l}\text { Tingkat pendayagunaan } \\
\text { Teknologi }\end{array}$} \\
\hline & & $\begin{array}{l}\text { Modal } \\
\text { (juta) }\end{array}$ & $\begin{array}{l}\text { Tenaga } \\
\text { Kerja }\end{array}$ & Skor & Kriteria & Klasifikasi \\
\hline Mixed & 23 & 71,61 & 7 Orang & 14.09 & \multirow{3}{*}{$\begin{array}{l}14.66 \leq x \leq \\
4\end{array}$} & Rendah \\
\hline $\begin{array}{l}\text { Non } \\
\text { Traditional } \\
\end{array}$ & 1 & 70 & 8 Orang & 14.60 & & Rendah \\
\hline $\begin{array}{l}\text { Fully } \\
\text { Traditional }\end{array}$ & 5 & 15 & 2 Orang & 8.00 & & Rendah \\
\hline
\end{tabular}

Sumber: Analisis Penyusun, 2013

\section{Analisis Tingkat Keberhasilan Pendayagunaan Teknologi}

Analisis tingkat keberhasilan pendayagunaan teknologi didasarkan pada faktor-faktor yang menjadi tolak ukur yang diungkapkan oleh Sudarmo (2005) dalam Mizar (2008), diantaranya faktor kelayakan teknis, faktor ekonomis, penerimaan oleh masyarakat, dan keserasian dengan lingkungan. 
TABEL 2

SINTESA ANALISIS TINGKAT KEBERHASILAN PENDAYAGUNAAN TEKNOLOGI

\begin{tabular}{|c|c|c|}
\hline $\begin{array}{l}\text { Komponen } \\
\text { Penilaian }\end{array}$ & Skor & Keterangan \\
\hline \multicolumn{3}{|r|}{ Faktor Kelayakan Teknis } \\
\hline $\begin{array}{l}\text { Peningkatan Nilai } \\
\text { Tambah }\end{array}$ & 61 & $\begin{array}{l}\text { Pendayagunaan teknologi sudah bisa menghasilkan nilai tambah, namun } \\
\text { beberapa pelaku usaha kurang bisa merasakan karena terkendala faktor } \\
\text { teknis peralatan yang membuat produksi kurang maksimal dan biaya } \\
\text { produksi yang mahal. }\end{array}$ \\
\hline $\begin{array}{l}\text { Membantu Proses } \\
\text { Produksi }\end{array}$ & 66 & $\begin{array}{l}\text { Pendayagunaan teknologi sudah bisa membantu proses produksi, namun } \\
\text { kurang maksimal karena jumlah peralatan pelaku usaha \& yang ada di UPT } \\
\text { terbatas dan rata-rata usia mesin tua sehingga produktifitas kurang. }\end{array}$ \\
\hline $\begin{array}{l}\text { Hemat dalam } \\
\text { sumberdaya }\end{array}$ & 70 & $\begin{array}{l}\text { Teknologi yang digunakan hemat dalam menggunakan sumberdaya listrik, } \\
\text { namun untuk sumberdaya berupa bahan bakar solar dibutuhkan dalam } \\
\text { jumlah besar dan cenderung kurang hemat. }\end{array}$ \\
\hline Awet & 72 & $\begin{array}{l}\text { Teknologi yang digunakan awet meskipun usianya cenderung tua. Awet } \\
\text { tidaknya teknologi tergantung perawatan dan cara pemakaian. }\end{array}$ \\
\hline Kesimpulan & 269 & $\begin{array}{l}\text { Pendayagunaan teknologi agak berhasil berdasarkan faktor kelayakan } \\
\text { teknis dengan total skor } 269 \text { dan memenuhi kriteria } 270,67 \leq \text { skor } \leq 193,34\end{array}$ \\
\hline \multicolumn{3}{|r|}{ Faktor Ekonomis } \\
\hline $\begin{array}{l}\text { Peningkatan } \\
\text { Keuntungan } \\
\text { Finansial }\end{array}$ & 65 & $\begin{array}{l}\text { Dengan bertambahnya peralatan dan perubahan teknologi, keuntungan } \\
\text { finansial meningkat cukup signifikan, namun ada pelaku usaha yang kurang } \\
\text { bisa merasakan karena kendala teknis yang menghambat produksi, modal } \\
\text { usaha yang besar, adanya persaingan yang kurang sehat, serta order yang } \\
\text { tidak menentu setiap bulannya sehingga keuntungan kurang bisa } \\
\text { diprediksi. }\end{array}$ \\
\hline Kesimpulan & 65 & $\begin{array}{l}\text { Pendayagunaan teknologi agak berhasil berdasarkan faktor ekonomis } \\
\text { dengan total skor } 65 \text { dan memenuhi kriteria } 67,67 \leq \text { skor } \leq 48,34\end{array}$ \\
\hline \multicolumn{3}{|r|}{ Faktor Penerimaan oleh Masyarakat } \\
\hline $\begin{array}{l}\text { Kemudahan } \\
\text { Penggunaan dan } \\
\text { Adopsi }\end{array}$ & 79 & $\begin{array}{l}\text { Teknologi termasuk dalam peralatan standart yang cenderung mudah } \\
\text { dipelajari dan sesuai dengan kemampuan pelaku usaha sehingga mudah } \\
\text { digunakan dan diadopsi di klaster komponen kapal. }\end{array}$ \\
\hline $\begin{array}{l}\text { Memberikan } \\
\text { Manfaat yang Besar }\end{array}$ & 73 & $\begin{array}{l}\text { Teknologi membawa manfaat yang besar di dalam klaster komponen kapal, } \\
\text { karena tanpa adanya teknologi, produksi klaster tidak bisa berjalan. }\end{array}$ \\
\hline $\begin{array}{l}\text { Kemudahan } \\
\text { Menjangkau }\end{array}$ & 60 & $\begin{array}{l}\text { Peralatan produksi cenderung mahal, sehingga pelaku usaha hanya bisa } \\
\text { membeli peralatan second dengan usia tua sesuai dengan kemampuan } \\
\text { ekonomi mereka. }\end{array}$ \\
\hline $\begin{array}{l}\text { Kesesuaian dengan } \\
\text { Budaya Mayarakat }\end{array}$ & 76 & $\begin{array}{l}\text { Industri komponen kapal sudah ada sejak dulu, sehingga aktivitas produksi } \\
\text { termasuk di dalamnya pendayagunaan teknologi tidak menjadi masalah } \\
\text { dan sudah sesuai dengan budaya masyarakat. }\end{array}$ \\
\hline Kesimpulan & 288 & $\begin{array}{l}\text { Pendayagunaan teknologi berhasil berdasarkan faktor penerimaan oleh } \\
\text { masyarakat dengan total skor } 288 \text { dan memenuhi kriteria } 348 \leq \text { skor < } \\
270,67\end{array}$ \\
\hline \multicolumn{3}{|r|}{ Faktor Keserasian dengan Lingkungan } \\
\hline $\begin{array}{l}\text { Tidak Menimbulkan } \\
\text { Pencemaran }\end{array}$ & 76 & $\begin{array}{l}\text { Limbah padat berupa scrap, potongan bahan baku, serta abu dimanfaatkan } \\
\text { lagi untuk pengecoran \& dijual sehingga tidak mencemari. Pencemaran } \\
\text { terkadang berasal dari asap pengecoran dan kebisingan, namun sejauh ini } \\
\text { masyarakat tidak merasa terganggu karena sudah terbiasa dengan hal } \\
\text { tersebut. }\end{array}$ \\
\hline Kesimpulan & 76 & $\begin{array}{l}\text { Pendayagunaan teknologi berhasil berdasarkan faktor keserasian dengan } \\
\text { lingkungan dengan total skor } 76 \text { dan memenuhi kriteria } 87 \leq \text { skor }<67,67\end{array}$ \\
\hline $\begin{array}{l}\text { Kesimpulan } \\
\text { Keseluruhan }\end{array}$ & 698 & $\begin{array}{l}\text { Pendayagunaan teknologi berhasil berdasarkan keempat faktor tersebut } \\
\text { dengan total skor } 698 \text { dan memenuhi kriteria } 870 \leq \text { skor }<676,67\end{array}$ \\
\hline
\end{tabular}

Sumber: Analisis Penyusun, 2013 
Kaitannya dengan tingkat keberhasilan pendayagunaan teknologi berdasarkan faktor ekonomis yang didalamnya meliputi peningkatan keuntungan finansial, dibandingkan antara kondisi dulu dengan sekarang dimana tentunya terdapat beberapa perubahan terkait dengan teknologi seperti perubahan peralatan dari manual menjadi manual elektrik, penambahan jumlah peralatan, serta perbaikan metode produksi. Berdasarkan hasil uji beda rata-rata ( $t$ test), diketahui rata-rata peningkatan keuntungan finansial sebesar Rp 5.105.000,00. Hasil $t$ hitung $(-5,373)<t$ table $(1,701)$ maka Ho ditolak, yang berarti bahwa peningkatan keuntungan finansial tersebut signifikan.

\section{Analisis Pengaruh Pendayagunaan Teknologi terhadap Klaster}

Pendayagunaan teknologi tentunya membawa pengaruh terhadap klaster komponen kapal Desa Kebasen, Kecamatan Talang, Kabupaten Tegal. Pengaruh ini dilihat berdasarkan aspek produksi yang mencakup peningkatan produktivitas, efisiensi waktu, penurunan produk cacat, dan efektivitas volume produksi. Pengaruh pendayagunaan teknologi dilakukan dengan membandingkan kondisi klaster dulu dengan saat ini. Industri komponen kapal tentunya telah mengalami perkembangan terutama dalam pendayagunaan teknologinya. Perkembangan ini bisa berupa perubahan peralatan produksi dari tradisional menjadi lebih modern, perkembangan kualitas peralatan produksi, penambahan alat produksi, atau perubahan metode produksi yang sebelumnya kurang prosedural sekarang menjadi lebih prosedural dan sudah ada pembagian jobdesk, sehingga hal ini tentunya membawa pengaruh terhadap pengembangan klaster.

1. Peningkatan Produktivitas

Produktivitas masing-masing unit usaha berbeda-beda, hal ini disebabkan karena jenis barang, jumlah produksi, dan jumlah tenaga kerja setiap unit usaha juga berbeda-beda. Secara keseluruhan, produktivitas di klaster komponen kapal meningkat sebesar 47,67\%. Pendayagunaan teknologi sudah membawa pengaruh terhadap peningkatan produktivitas, meskipun bagi sebagian pelaku usaha merasa peningkatan produktivitas seharusnya bisa lebih maksimal jika kondisi peralatan dan jumlahnya lebih layak dan mencukupi secara kualitas maupun kuantitas. Berdasarkan hasil uji beda rata-rata ( $t$-test), diketahui rata-rata peningkatan produktivitas sebesar 42,741 item/tenaga kerja/bulan. Hasil t hitung $(-4,685)<$ t table $(1,701)$ maka Ho ditolak, yang berarti peningkatan produktivitas tersebut signifikan.

2. Peningkatan Efisiensi Waktu

Efisiensi waktu produksi setiap unit usaha di Klaster komponen kapal berbeda-beda, tergantung pada jenis produk yang dihasilkan karena masing-masing produk memiliki ukuran dan tingkat kerumitan yang berbeda-beda dalam proses produksinya. Jika ditinjau secara keseluruhan, kecepatan waktu produksi di klaster komponen kapal mengalami peningkatan sebesar 48,44\%. Berkembangnya beberapa peralatan produksi dari yang dahulu dioperasikan penuh oleh manusia dan sekarang telah menggunakan listrik, penambahan peralatan produksi, perbaikan metode produksi, dan perkembanganperkembangan lain di dalam klaster komponen kapal memang membuat waktu produksi menjadi lebih cepat, sehingga produk yang dihasilkan menjadi lebih banyak. Berdasarkan hasil uji beda rata-rata ( $t$-test), diketahui bahwa waktu produksi menjadi lebih cepat yaitu rata-rata menghemat waktu produksi 61,483 menit. Namun berdasarkan uji beda rata-rata, hasil t hitung $(3.772)>t$ table $(1,701)$ maka Ho diterima, yang berarti peningkatan efisiensi waktu produksi tersebut belum signifikan.

3. Penurunan Produk Cacat

Di klaster komponen kapal, penurunan produk cacat memang belum signifikan. Secara keseluruhan, penurunan produk cacat di klaster komponen kapal sebesar 10,17\%. 
Teknologi/peralatan produksi yang digunakan dalam proses pengecoran masih menggunakan dapur atau kompor manual (sistem tradisional), begitu pula dalam proses penuangan dan pencetakannya. Di dalam kedua proses tersebut tenaga manusia masih sangat dominan sehingga produk cacat yang dihasilkan masih cenderung besar. Di dalam proses machining, keterlibatan teknologi serta perkembangannya dari yang semula manual menjadi manual elektrik cukup membantu dalam mengurangi produk cacat. Penurunan produk cacat tidak hanya dipengaruhi oleh pendayagunaan teknologi saja namun juga sumberdaya manusianya yang meliputi ketelitian, kecermatan, dan ketrampilan dalam proses penciptaan produk.

4. Peningkatan Efektivitas Volume Produksi

Peningkatan volume produksi menunjukkan perkembangan usaha setiap unit usaha di klaster komponen kapal yang tentunya berbeda-beda. Peningkatan volume produksi ini disebabkan bertambahnya jumlah peralatan produksi dan tenaga kerja, selain itu faktor perkembangan beberapa teknologi dari yang semula manual menjadi manual elektrik, dan lain sebagainya. Secara keseluruhan, peningkatan efektivitas volume produksi di klaster komponen kapal ini mencapai 47,60 \%. Berdasarkan hasil uji beda rata-rata (t-test), diketahui rata-rata peningkatan volume produksi sebesar 286,310 item/bulan. Hasil t hitung $(-3,890)<\mathrm{t}$ table $(1,701)$ maka Ho ditolak, yang berarti peningkatan volume produksi tersebut signifikan.

Untuk lebih jelasnya mengenai pengaruh pendayagunaan teknologi ini dilihat berdasarkan aspek produksi dan perbedaan antara masing-masing klasifikasi mixed, non traditional, dan fully traditional, dapat dilihat pada bagan di bawah ini:

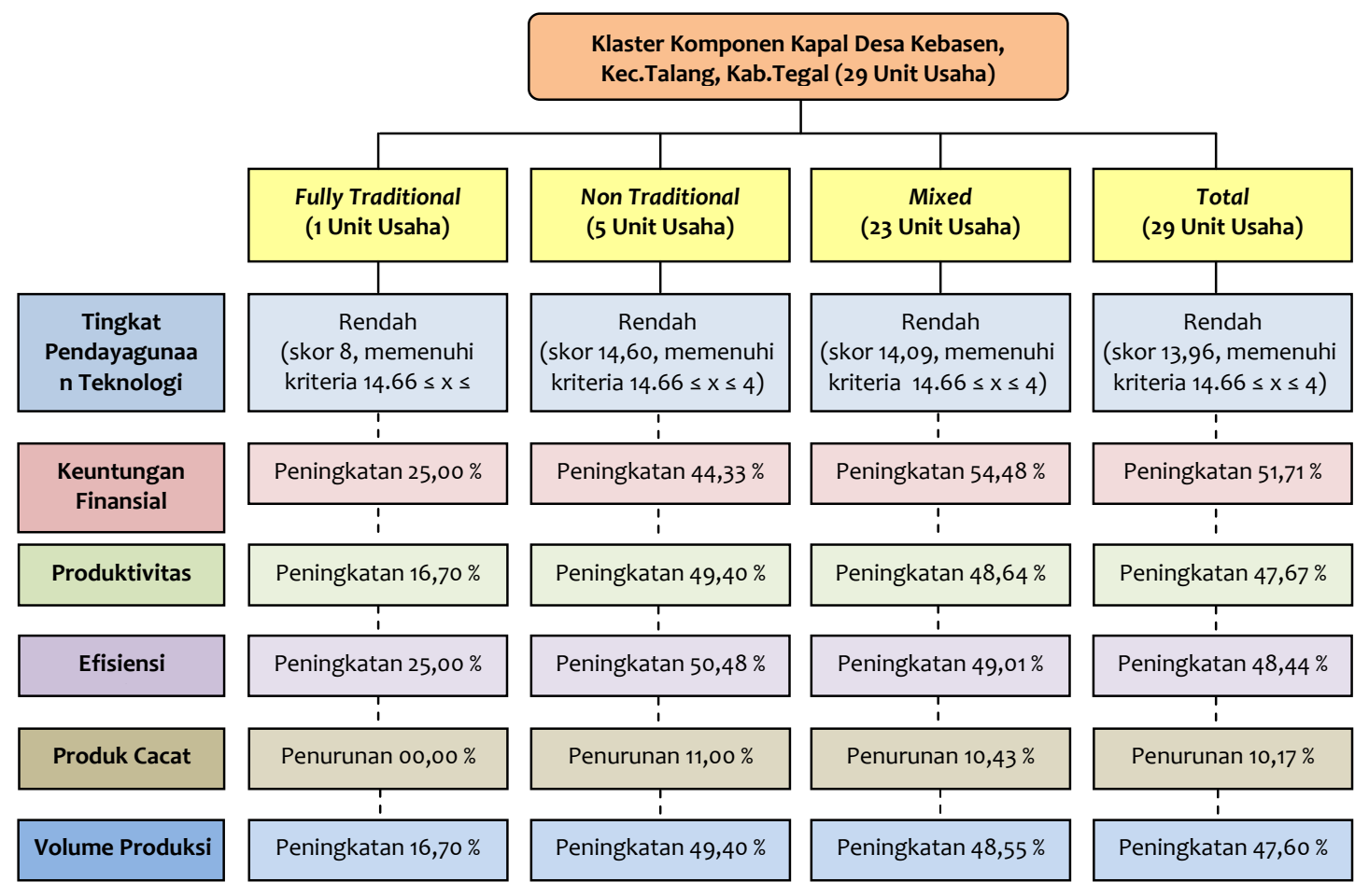

Sumber : Analisis Penyusun, 2013 


\section{KESIMPULAN}

1. Klaster belum membutuhkan high technology karena disesuaikan dengan kebutuhan produksi yang masih kelas usaha kecil dan menengah, kondisi ekonomi, dan SDM pelaku usaha.

2. Pendayagunaan teknologi di dalam klaster menggunakan peralatan produksi manual dan manual elektrik.

3. Tingkat pendayagunaan teknologi untuk klasifikasi unit usaha Mixed, Non traditional, Fully Traditional termasuk dalam tingkat Pendayagunaan teknologi rendah. Secara keseluruhan tingkat pendayagunaan teknologi di klaster komponen kapal termasuk rendah.

4. Pendayagunaan teknologi dinyatakan agak berhasil berdasarkan faktor kelayakan teknis dan ekonomis, serta dinyatakan berhasil berdasarkan faktor penerimaan oleh masyarakat dan keserasian dengan lingkungan.

5. Pendayagunaan teknologi membawa pengaruh terhadap klaster yaitu pada aspek produksi karena dapat meningkatkan produktivitas sebesar 47,67\% dimana peningkatan ini termasuk signifikan berdasarkan uji t, efisiensi waktu produksi 48,44\% dimana peningkatan ini belum signifikan berdasarkan uji t, dan volume produksi 47,60 \% dimana peningkatan ini termasuk signifikan berdasarkan uji $t$, meskipun tidak semua pelaku usaha mengalami peningkatan yang signifikan. Selain itu berpengaruh juga dalam penurunan produk cacat sebesar 10,17\% terutama dalam proses machining karena terdapat perkembangan peralatan dari manual menjadi manual elektrik serta peningkatan SDM, namun belum berpengaruh di dalam proses pengecoran karena masih menggunakan sistem tradisional.

\section{DAFTAR PUSTAKA}

Albu, Michael. 1997. Technological Learning and Innovation in Industrial Clusters in the South. Science Policy Research Unit University of Sussex.

Alkadri. 1999a. Tiga Pilar Pengembangan Wilayah: Sumberdaya Alam, Sumberdaya Manusia, Teknologi. Jakarta: Penerbit Direktorat Kebijaksanaan Teknologi untuk Pengembangan Wilayah Badan Pengkajian dan Penerapan Teknologi.

- 1999b. Manajemen Teknologi untuk Pengembangan Wilayah. Jakarta: Penerbit Pusat Pengkajian Kebijakan Teknologi untuk Pengembangan Wilayah Badan Pengkajian dan Penerapan Teknologi.

Cooke, Philip and Andrea Piccaluga. 2007. Regional Development in the Knowledge Economy. New York: Routledge.

Ellitan, Lena. 2003. "Peran Sumber Daya dalam Meningkatkan Pengaruh Teknologi terhadap Produkvitas." Jurnal Manajemen \& Kewirausahaan, Vol. 5, No. 2, September, hal. 155 170. Dalam http://puslit.petra.ac.id/journals/management/.

Knaap, Bert Van Der and Egbert Wever. 2003. New Technology and Regional Development. New Hampshire: Croom Helm.

Mizar, Alfian et al. 2008. "Tipologi dan Karakteristik Adopsi Teknologi Pada Industri Kecil Pengolah Hasil Pertanian." Makalah disampaikan pada Gelar Teknologi dan Seminar Nasional Teknik Pertanian Jurusan Teknik Pertanian Fakultas Teknologi Pertanian UGM, Yogyakarta, November 18-19, 2008.

Rietveld, Piet. 1987. “Adopsi Inovasi Teknologi dalam Industri Kecil.” Majalah Prisma No. IV, April. Jakarta: LP3ES.

Youseff, M.A. 1993. "Computer Based Technology and Their Impact on Manufacturing Flexibility." International Journal of Technology Management, Vol. 8, pp. 355-370. 